\title{
AMPA receptor potentially participates in the mediation of the increased brain-derived neurotrophic factor following chronic ketamine use
}

\author{
Jianjun Yang $\cdot$ Zhiqiang Zhou $\cdot$ Chun Yang
}

Received: 6 June 2011 / Accepted: 6 October 2011 /Published online: 19 October 2011

(C) Springer-Verlag 2011

We read with great interest the recently published article "Chronic ketamine use increases serum levels of brain-derived neurotrophic factor" by Ricci et al. (2011). In this study, the authors considered that the mechanism underlying the increased serum levels of BDNF in chronic ketamine use are attributed to the antagonistic action of $N$-methyl-D-aspartate (NMDA) receptor. However, the intracellular glutamate release increased by ketamine administration preferentially favors $\alpha$-amino-3-hydroxy-5-methyl-4-isoxazolepropionic acid (AMPA) receptor over NMDA receptor because the latter is occupied by ketamine (Machado-Vieira et al. 2009). Moreover, several studies have demonstrated that AMPA receptor mediates the increase of BDNF via two distinct signaling pathways. The first pathway involves the increases in intracellular calcium concentration, which subsequently leads to the upregulation of BDNF gene expression through calcium response elements (Tao et al. 1998). The second pathway depends on the activation of
Lyn, a member of the src family of protein tyrosine kinases, which upregulates the mitogen-activated protein kinase pathway and then leads to the increases of BDNF expression (Hayashi et al. 1999).

\section{References}

Hayashi T, Umemori H, Mishina M, Yamamoto T (1999) The AMPA receptor interacts with and signals through the protein tyrosine kinase Lyn. Nature 397:72-76

Machado-Vieira R, Salvadore G, Diazgranados N, Zarate CA Jr (2009) Ketamine and the next generation of antidepressants with a rapid onset of action. Pharmacol Ther 123:143-150

Ricci V, Martinotti G, Gelfo F, Tonioni F, Caltagirone C, Bria P, Angelucci F (2011) Chronic ketamine use increases serum levels of brain-derived neurotrophic factor. Psychopharmacology (Berl) 215:143-148

Tao X, Finkbeiner S, Arnold DB, Shaywitz AJ, Greenberg ME (1998) $\mathrm{Ca}^{2+}$ influx regulates BDNF transcription by a CREB family transcription factor-dependent mechanism. Neuron 20:709-726

J. Yang $\cdot$ Z. Zhou $\cdot$ C. Yang $(\bowtie)$

Department of Anesthesiology, Jinling Hospital,

School of Medicine, Nanjing University,

Nanjing, China

e-mail: yangchuntz@sina.com 